\title{
Верификация зараженности корней картофеля золотистой картофельной нематодой
}

\author{
А.В. Хютти*, Н.В. Мироненко, О.С. Афанасенко \\ Всероссийский научно-исследовательский институт защчиты растений, Санкт-Петербург, \\ Пушкин, Россия \\ *e-mail: alexanderkhyutti@mail.ru
}

Дикие виды картофеля представляют особый интерес для поиска новых генов устойчивости к глободерозу. Для проведения транскриптомного анализа зараженного растения на разных временных этапах после внесения инокулюма, необходимо подтвердить факт заражения, то есть внедрения личинок нематоды в ткань корня. Молекулярная диагностика золотистой картофельной нематоды Globodera rostochiensis была разработана для идентификации нематоды в почвенных образцах (Bulman, Marshall, 1997). Для контроля за внедрением личинок золотистой картофельной нематоды (ЗКН) G. rostochiensis патотипа Ro1 в корни образцов Solanum tuberosum и S. phureja, используемых для транскриптомного анализа, мы применили метод ПЦР диагностики и цитологический анализ. Для окрашивания зараженных корней, с целью цитологического контроля внедрения личинок G. rostochiensis, использовали краситель - 0,05 \% кислый фуксин $\left(\mathrm{C}_{20} \mathrm{H}_{20} \mathrm{~N}_{3} \mathrm{Cl}\right)$. Корни картофеля промывали $\mathrm{H}_{2} \mathrm{O}$, переносили в раствор кислого фуксина на 10 с и повторно промывали $\mathrm{H}_{2} \mathrm{O}$. В дальнейшем окрашенные и разрезанные корни переносили на покровные стекла и просматривали с помощью стереоскопического микроскопа Carl Zeiss Axio Scope 40 (ув. 200x). Нашей задачей было подобрать условия ПЦР для обнаружения G. rostochiensis в корнях сорта Невский S. tuberosum и образцах дикого вида $S$. phureja. Для анализа брали корни $S$. tuberosum в следующие временные интервалы: через 3, 24, 72 ч и 5, 8 суток после заражения. Всю массу замороженных корней растирали в жидком азоте. Для выделения ДНК от каждого образца брали навеску корней 200-300 мг. Выделение ДНК из корней картофеля проводили с использованием СТАВ. Для доказательства факта заражения ставили ПЦР с видоспецифичными для G. rostochiensis праймерами (Bulman, Marshall, 1997): PITSp4 (5'-ACAACAGCAATCGTCGAG-3') и PITSr3 (5'-AGCGCAGACATGCCGCAA-3'). Положительным контролем служила ДНК, выделенная из 200 цист нематоды и растворенная в 200 мкл воды. Негативным контролем служила вода и ДНК незараженного растения. Показано, что контрольные варианты образцов корней незараженных растений дают в ПЦР неспецифические продукты амплификации того же размера, что и ДНК нематоды. Чтобы убрать неспецифическое праймирование, мы уменьшили концентрацию хлорида магния. Для амплификации видоспецифичного фрагмента ЗКН в корнях растений были подобраны две программы: стандартная и ступенчатая (touchdown) с температурой отжига праймеров 57 и $60{ }^{\circ} \mathrm{C}$ соответственно. У всех зараженных образцов сорта Невский выявлены диагностические продукты амплификации, свидетельствующие о факте заражения нематодой. В незараженных образцах $S$. phureja не обнаружен диагностический продукт амплификации с видоспецифичными к G. rostochiensis праймерами. В зараженных корнях растений устойчивого образца $S$. phureja выявлены слабые диагностические фрагменты в вариантах 24 и 72 ч после заражения. У восприимчивого образца интенсивность продуктов амплификации была выше, чем в устойчивом. Это различие может быть связано с генетической детерминацией устойчивости, влияющей на количество внедрений патогена и развитие его внутри корня. Цитологическим методом нематода обнаружена в самом «раннем» варианте 3 ч после заражения и последующих. Мы показали, что условия ПЦР с видоспецифичными праймерами PITSp4 и PITSr3 для идентификации нематоды в корнях $S$. phureja и $S$. tuberosum различны.

Благодарности: Работа выполнена при финансовой поддержке гранта РНФ № 16-16-04073. 